Сергій Горбачевський, кандидат технічних наук, старший науковий співробітник Національний університет оборони України імені Івана Черняховського

ORCID ID 0000-0002-4946-1604

Михайло Орда, кандидат технічних наук, старший науковий співробітник Національний університет оборони України імені Івана Черняховського ORCID ID 0000-0003-0374-3881

DOI: $10.33099 / 2617-1775 / 2020-01 / 103-108$

\title{
НАПРЯМКИ ВИКОРИСТАННЯ СУЧАСНИХ ТЕХНОЛОГІЙ В ІНФОРМАЦЙНОМУ ЗАБЕЗПЕЧЕННІ СИСТЕМИ ВІЙСЬКОВОЇ ОСВІТИ
}

Сучасні умови існування армій характеризуються високим рівнем вимог до професійних знань $і$ навичок з одного боку і старінням знань в умовах швидкоплинних змін світу з іншого боку. Тому освітній процес повинен бути безперервним $і$ розподіленим територіально. Забезпечити виконання цих умов (вимог часу) можна тільки $з$ використанням сучасних інформачійних технологій, які повинні застосовуватися в освітній діяльності вищих військових навчальних закладів. У статті проаналізовано сучасний досвід використання інформаційних систем в військовій освіті $i$ сформульовані проблемними питання, які потрібно вирішити.

Ключові слова: вищчі військові навчальні заклади; військова освіта; інформаційні системи; дистанційне навчання; інформаційне освітнє середовище.

Постановка проблеми. Стан ринку електронного навчання (E-Learning) в глобальному масштабі продовжує рости і розвиватися. Це підтверджується зростаючими витратами на розвиток середовищ електронного навчання, особливо в провідних країнах світу, зростаючої географією поширення електронного навчання і зростаючим різноманітністю освітніх платформ. В умовах обмеженості ресурсів України на армію і військову освіту зокрема, стоїть актуальне завдання вивчення передового досвіду електронного навчання і впровадження кращих практик в освітній процес.

В цілому, система електронного навчання пройшла довгий історичний шлях. Ще в 1840 році сер Айзек Питман, британський учений-стенограф i релігійний діяч, винахідник стенографії використовував скорочену форму навчання за допомогою поштового листування. По суті, це перший дистанційний курс в історії освіти. Згодом, формат доставки навчального контенту пройшов кілька етапів розвитку - починаючи від поштової доставки друкованих матеріалів і закінчуючи спеціальними додатками для смартфонів і віртуальними середовищами.

Радянський Союз 3 його величезними територіями теж активно використовував дистанційне навчання. I це не тільки заочне навчання у 
закладах вищої освіти, а й заочні фізико-математичні та хімічні школи для обдарованих школярів та таке інше.

Аналіз останніх досліджень. Реальне зростання технологій дистанційного навчання почалось 3 появою Інтернету і триває досі. Причому, якщо на етапі становлення більше уваги приділяли надійності застосовування технологій, то зараз на перший план виходять інтерфейси, тобто зручність користування, інтерактивні можливості i можливість використання нових педагогічних прийомів.

Серед вітчизняних авторів, чиї роботи присвячені дослідженню потенціалу електронного навчання взагалі і в ВВН3, зокрема, слід віднести В.М. Кухаренко, М.Л. Смульсон, К.Л. Бугайчук [1-3].

Виклад основного матеріалу дослідження. У 1996 році Міністерство оборони США затвердив концепцію програми дистанційного навчання арміі (The Army Distance Learning Program - TADLP). Ця програма була розроблена для віддаленого індивідуального і колективного навчання. В рамках були реалізовані різноманітні освітні технології від відеоконференцій i інтерактивних мультимедіа підручників до веб-курсів і електронних журналів. Це дозволило солдатам пройти самостійне навчання за більш ніж 500 курсів в різних галузях знань.

У січні 2001 року Міністерство оборони США розпочало роботу над великомасштабним проектом повсюдного впровадження електронного навчання під назвою «Доступний університет» (Army University Access Online), який більш відомий під назвою свого інтернет-порталу eArmyU.

eArmyU солдатові доступ до більш ніж 100 курсів в акредитованих регіональних коледжах i університетах. За допомогою еArmyU вони мають можливість отримати сертифікат або диплом про підвищення кваліфікації, ступінь бакалавра або магістра в коледжі, а також прослухати курси в декількох коледжах. Веб-курси пропонують унікальну можливість вчитися в будь-який час і в будь-якому місці, поряд з виконанням своїх службових обов'язків.

У 2005 році в Свропі було створено Свропейський коледж 3 питань у сфері безпеки та оборони (European Security and Defence College - ESDC) 3 метою забезпечення відповідності освітнього процесу політиці Європейського союзу 3 питань національної безпеки і оборони.

ESDC - це свого роду мережевий коледж, що включає в себе близько 120 університетів, академій, коледжів та інститутів, а також добре відомих в Свропі цивільних і військових освітніх і дослідницьких установ.

В системі військової освіти України (CBO) завжди приділялася значна увага інформаційним системам у освіті. Для керівництва цим напрямком в управлінні військової освіти ще в 90-ті роки був створений відділ науковометодичного забезпечення впровадження новітніх інформаційних технологій [4].

На першому етапі основними завдання CBO у цьому напрямку були забезпечення ВВНЗ комп'ютерами та підключення до мереж Інтранету та Інтернету. 3 часом, сталі зрозумілі переваги електронної освіти та необходимость впровадження віртуальних навчальних середовищ. Перед ВВНЗ 
постало завдання вибору програмних платформ для дистанційного навчання (СДН, LMS - Learning Management System).

Більшість українських ВНЗ, не тільки військових, зробили свій вибір на користь платформи Moodle (Modular Object-Oriented Dynamic Learning Environment). Це безкоштовне програмне забезпечення (ПЗ) 3 відкритим первинним кодом. Крім безкоштовності, у Moodle $\epsilon$ ще ряд переваг, які зумовили його популярність на просторах колишнього СРСР. Це наявність готових шаблонів, простий і динамічний інтерфейс, який легко налаштовується, досить велика спільнота розробників, які розробляють нові шаблони і плагіни, зручний мобільний додаток і так далі.

Тим часом, у безкоштовного продукту $є$ i певні недоліки - відсутність технічної підтримки i необхідність мати у викладачів навичок вебпрограмування.

Безкоштовність ПЗ забезпечила дешевий і швидкий старт дистанційного навчання в ВВНЗ. Однак з часом стало зрозуміло, що подібна децентралізована система в рамках $\mathrm{CBO}$ не $\epsilon$ оптимальною, оскільки вимагає розгортання серверного обладнання в кожному ВВН3, навчання викладачів і така система слабо пристосована до обміну кращими практиками.

В рамках СВО більш доцільною виглядає централізована СДН 3 центральним репозиторіем ресурсів (ЦРР) і дистанційним доступом викладачів i слухачів ВВНЗ. Таку систему легше і дешевше обслуговувати. Від ВВНЗ потрібно тільки оцифровувати і викладати на хостінг навчальні курси, а також забезпечувати своєчасне дистанційне навчання самих викладачів роботі в системі Moodle.

Наразі ЦРР ЗСУ знаходиться за електронною адресою http://adl.mil.gov.ua Порядок роботи ЦРР визначається наказом Міністерства оборони України від 21 грудня 2015 року №744 «Про затвердження Концепції дистанційного навчання у Збройних Силах України».

До речі, Moodle далеко не єдина безкоштовна LMS, є ще альтернативи. Наприклад, LMS Ilias - поширена в Німеччині, Польщі, та й самої НАТО. Особливістю сучасного етапу розвитку військових СДН є обмеження щодо режиму секретності. Цифровізації підлягають тільки нетаємні дисципліни i курси. У НАТО і, особливо США, це проблема вирішена за допомогою захищених сховищ даних, мереж доступу і пристроїв, 3 яких здійснюється доступ.

Крім того, централізована СДН краще пристосована до взаємодії 3 міжнародними партнерами в рамках програм НАТО. На сьогодні Україна приєдналася до низки програм 3 міжнародного військового співробітництва, які дозволяють вітчизняним військовослужбовцям підвищувати свій професійний рівень за декількома напрямками: вивчення іноземних мов, опанування новітніх систем зв'язку та управління, набуття навичок з оперативного командування тощо.

В якості прикладу зазначимо, що наша держава бере участь у програмі IMET (International Military Education and Training) - це міжнародна програма військової освіти та підготовки (США), до якої Україна приєдналася у 
1992 році з метою підготовки висококваліфікованих офіцерів, осіб рядового, сержантського і старшинського складу та працівників 3С України. Витрати Уряду США на підготовку представників Міністерства оборони України за Програмою ІМЕТ за весь період ії реалізації склали понад 16 млн доларів США. Протягом останніх років для реалізації Програми IMET в Україні щороку виділяється 50-60 навчальних місць у військових закладах США[5].

Наступна програма 3 міжнародного військового співробітництва до якої долучилась Україна має назву DEEP-2012 (Defence Education Enhancement Program) - це програма удосконалення військової освіти. Програма НАТО «Удосконалення військової освіти» забезпечує зв'язок між освітянами держав членів і партнерів Альянсу з метою удосконалення програм і методик навчання військовослужбовців. Україна приєдналася до Програми з жовтня 2012 року [6].

Однак, як свідчить досвід, використання електронного освітнього середовища, крім беззаперечних переваг (оперативність обробки даних, використання єдиної бази даних навчально-методичних матеріалів, використання система як під час занять, так і під час самостійної підготовки учнів), має і недоліки або труднощі.

Зокрема, проблемними питаннями використання СДН є:

слабка підготовка професорсько-викладацького складу і методистів, які займаються створенням електронних навчальних курсів;

недостатнє матеріально-технічне забезпечення освітнього процесу;

«опір» 3 боку найбільш вікової частини професорсько-викладацького складу;

дорожнеча i складність розробки i впровадження електронної інформаційно-освітнього середовища в освітній процес;

конкуренція за IT-фахівців 3 боку комерційних структур, де зарплати істотно вище;

невідповідність штатних оргструктур потребам СДН;

забезпечення безпечного режиму для роботи з секретними даними.

Тому зараз в СДН впроваджуються тільки нетаємні курси. Окрім зазначеного, слід наголосити про певне відставання з розробкою нормативноправових актів. Нормативно-правові акти, що потребують розроблення у першу чергу:

наказ Міністерства оборони України щодо запровадження ДН у Збройних Силах України;

Положення про ДН у Збройних Силах України;

Типове положення про ДН у військовому навчальному закладі Збройних Силах України;

Висновки. Система військової освіти в Україні в частині дистанційного навчання знаходиться в стадії активного розвитку і впровадження кращих практик викладання нетаємних дисциплін і курсів. Проблемним залишається завдання створення інфраструктури для роботи із закритою інформацією. Звичайно, що це буде наступним етапом розвитку СДН. 


\section{ЛІТЕРАТУРА}

1. Теорія та практика змішаного навчання : монографія / В.М. Кухаренко, С.М. Березенська, К.Л. Бугайчук, Н.Ю. Олійник, Т.О. Олійник, О.В. Рибалко, Н.Г. Сиротенко, А.Л. Столяревська; за ред. В.М. Кухаренка - Харків: «Міськдрук», НТУ «ХПІ», 2016. - 284 с.

2. Дистанційне навчання: психологічні засади : монографія / М.Л. Смульсон, Ю.І. Машбиць, М.І. Жалдак та ін. ; за ред. М.Л. Смульсон. - Кіровоград : Імекс-ЛТД, 2012. $240 \mathrm{c}$.

3. Андрєєв О.О. Педагогічні аспекти відкритого дистанційного навчання : монографія / О.О. Андрєєв, К.Л. Бугайчук, Н.О. Каліненко, О.Г. Колгатін, В.М. Кухаренко, Н.А. Люлькун, Л.Л. Ляхоцька, Н.Г. Сиротенко, Н.Є. Твердохлєбова. // За ред. О.О. Андрєєва, В.М. Кухаренка - ХНАДУ, Харків: «Міськдрук», 2013. - 212 с.

4. Нещадим M.I. Військова освіта України: історія, теорія, методологія, практика : монографія. -К.:Видавничо-поліграфічний центр «Київський університет», 2003. - 852 с.

5. Biermann R. Inter-organizationalism in Theory and Practice. Studia Diplomatica. The Brussels Journal of International Relations. 2009. Vol. LXII. No. 3. P. 7-12.

6. Mayer S. Embedded Politics, Growing Informalization? How NATO and the EU Transform Provision of External Security. Contemporary Security Policy. 2011. Vol. 32. No. 2. P. 308-333.

\section{REFERENCES}

1. Teoriia ta praktyka zmishanoho navchannia : monohrafiia / V.M. Kukharenko, S.M. Berezenska, K.L. Buhaichuk, N.Iu. Oliinyk, T.O. Oliinyk, O.V. Rybalko, N.H. Syrotenko, A.L. Stoliarevska; za red. V.M. Kukharenka - Kharkiv: «Miskdruk», NTU «KhPI», 2016. - $284 \mathrm{s.}$

2. Dystantsiine navchannia: psykholohichni zasady : monohrafiia / M.L. Smulson, Yu.I. Mashbyts, M.I. Zhaldak ta in. ; za red. M.L. Smulson. — Kirovohrad : Imeks-LTD, 2012. - 240 s.

3. Andrieiev O.O. Pedahohichni aspekty vidkrytoho dystantsiinoho navchannia : monohrafiia / O.O. Andrieiev, K.L. Buhaichuk, N.O. Kalinenko, O.H. Kolhatin, V.M. Kukharenko, N.A. Liulkun, L.L. Liakhotska, N.H. Syrotenko, N.Ie. Tverdokhliebova. // Za red. O.O. Andrieieva, V.M. Kukharenka - KhNADU, Kharkiv: «Miskdruk», 2013. - 212 s.

4. Neshchadym M.I. Viiskova osvita Ukrainy: istoriia, teoriia, metodolohiia, praktyka : monohrafiia. -K.:Vydavnycho-polihrafichnyi tsentr «Kyivskyi universytet», 2003. - $852 \mathrm{~s}$.

5. Biermann R. Inter-organizationalism in Theory and Practice. Studia Diplomatica. The Brussels Journal of International Relations. 2009. Vol. LXII. No. 3. P. 7-12.

6. Mayer S. Embedded Politics, Growing Informalization? How NATO and the EU Transform Provision of External Security. Contemporary Security Policy. 2011. Vol. 32. No. 2. P. 308-333.

\section{PЕЗЮМЕ}

Сергей Горбачевский, кандидат технических наук, старший научный сотрудник Национальный университет обороны Украины имени Ивана Черняховского

Михаил Орда, кандидат технических наук, старший научный сотрудник

Национальный университет обороны Украины имени Ивана Черняховского

\section{Направления использования современных технологий в информационном обеспечении системы военного образования}

Современные условия существования армий характеризуются высоким уровнем требований к профессиональным знаниям и навыкам с одной стороны и старением знаний 8 
условиях быстрых изменений мира с другой стороны. Поэтому образовательный процесс должен быть непрерывным и распределенным территориально. Обеспечить выполнение этих условий (требований времени) можно только с использованием современных информационных технологий, которые долюны применяться в образовательной деятельности высших военных учебных заведений. В статье проанализирован современныи опыт использования информационных систем в военном образовании и сформулированы основные проблемные вопросы, которые нужно решить.

Ключевые слова: высиие военные учебные заведения; военное образование; информационные системы; дистаниионное обучение; информационная образовательная среда.

\section{SUMMARY}

Serhii Horbachevsky,

$\mathrm{PhD}$ (technical sciences), Senior Researcher National University of Defence of Ukraine Named after Ivan Chernyakhovskyi

Mikhailo Orda,

$\mathrm{PhD}$ (technical sciences), Senior Researcher National University of Defence of Ukraine Named after Ivan Chernyakhovskyi

\section{Directions of use modern information technologies in educational process of a high military school}

Introduction The modern conditions of existence of armies are characterized by a high level of requirements for professional knowledge and skills on the one hand and aging of knowledge in the conditions of rapid changes of the world on the other. Therefore, the educational process must be continuous and territorially distributed. These conditions (time requirements) can be fulfilled only with the use of modern information technologies, which should be applied in the educational activities of higher military educational institutions. The article analyzes the current experience of using information systems in military education and outlines the main problematic issues that need to be addressed.

Purpose The purpose of the article is to determine the directions of use of modern technologies in information support of the military education system.

Methods the system of general scientific and special methods of theoretical and empirical research, namely theoretical and methodological analysis of the problem, analysis of scientific literature on the problem of research, systematization and generalization of scientific information concerning the nature and content of certain tasks, monitoring of existing systems were used to solve the set research problems. training of military specialists in the Russian Armed Forces, scientific generalization, general scientific methods of logical and comparative analysis, systematic approach, expert zinc, analysis and interpretation of theoretical and empirical data.

Results the result of the article is a set of directions of use of modern technologies in the information support of the military education system.

Originality The article first analyzes the state of the distance learning system in military education and outlines ways to solve the main problems.

Conclusion The system of military education in Ukraine in terms of distance learning is in the stage of active development and implementation of best practices in teaching non-secret disciplines and courses. The problem remains the task of creating an infrastructure for handling classified information. Of course, this will be the next stage in the development of the distance learning system.

Key words: military education system, attestation, scientific direction, scientific and technical activity, methodology, system of indicators. 